\title{
Yield increase of corn inoculated with a commercial arbuscular mycorrhizal inoculant in Brazil
}

\author{
Shantau Camargo Gomes Stoffel ${ }^{1}$ (D) Cláudio Roberto Fonsêca Sousa Soares ${ }^{1^{*}}$ (D) Edenilson Meyer $^{1}$ (D) \\ Paulo Emílio Lovato ${ }^{2}$ Admir José Giachini ${ }^{1}$ (D)
}

${ }^{1}$ Departamento de Microbiologia, Imunologia e Parasitologia, Centro de Ciências Biológicas, Universidade Federal de Santa Catarina (UFSC), Campus João David Ferreira Lima, Trindade, 88040-970, Florianópolis, SC, Brasil. E-mail: crfsoares@gmail.com. *Corresponding author. ${ }^{2}$ Departamento de Engenharia Rural, Centro de Ciências Agrárias, Universidade Federal de Santa Catarina (UFSC), 88034-000, Florianópolis, SC, Brasil.

ABSTRACT: Arbuscular mycorrhizal fungi (AMF) play an important role in plant growth. However, there are no reports of legally commercialized AMF-based inoculants for agricultural crops in Brazil. The objective of this research was to evaluate the agronomic efficiency of a Rhizophagus intraradices inoculant in combination with phosphate fertilization in grain yield of corn under different edaphoclimatic conditions in Brazil. Experiments were conducted in five Brazilian states (Goiás, Mato Grosso, Minas Gerais, Rio Grande do Sul and Santa Catarina) in a $2 \times 3$ factorial scheme, with two inoculation treatments (inoculated and non-inoculated seeds) and three doses of phosphate fertilization (0, 50 and 100\% of the recommended P). At the end of the crop cycle (stages R4-R5), inoculation provided increases in biomass (average of $48 \%$ ) regardless of the applied dose of $P$, higher $P$ absorption, and $54 \%$ average increase in grain yield. In conclusion, the mycorrhizal inoculant increases biomass yield, $P$ uptake and corn grain yield under different edaphoclimatic conditions in Brazil, especially in soils that originally had low or medium levels of available $P$.

Key words: Rhizophagus intraradices, arbuscular mycorrhizae, phosphate fertilization, seed inoculant.

Rendimento de grãos da cultura do milho com inoculante micorrízico arbuscular comercial no Brasil

RESUMO: Os fungos micorrízicos arbusculares (FMA) desempenham um papel importante no crescimento das plantas, no entanto, não há relatos de inoculantes legais baseados em AMF para culturas agrícolas no Brasil. O objetivo deste trabalho foi avaliar a eficiência agronômica de um inoculante a base de Rhizophagus intraradices em combinação com a adubação fosfatada no rendimento de grãos de milho sob diferentes condições edafoclimáticas no Brasil. Os experimentos foram conduzidos em cinco estados brasileiros (Goiás, Mato Grosso, Minas Gerais, Rio Grande do Sul e Santa Catarina) em esquema fatorial $2 x 3$, com dois tratamentos de inoculação (sementes inoculadas e não inoculadas) e três doses de adubação fosfatada (0, 50 e 100\% do P recomendado). No final do ciclo da cultura (estágios $R 4-R 5)$, a inoculação proporcionou aumentos na biomassa (média de 48\%), independentemente da dose aplicada de $P$, maior absorção de $P$ e aumento médio de $54 \%$ no rendimento de grãos. Conclui-se que o inoculante micorrízico arbuscular aumenta a produção de biomassa, a absorção de P e a produtividade de grãos de milho em diferentes condições edafoclimáticas no Brasil, especialmente em solos que originalmente apresentavam níveis baixos ou médios de $P$.

Palavras-chave: Rhizophagus intraradices, micorriza arbuscular, adubação fosfatada, inoculação de sementes.

\section{INTRODUCTION}

Arbuscular mycorrhizae represent a symbiotic relationship between arbuscular mycorrhizal fungi (AMF) and plant roots of various species with attested benefits for plant growth (SMITH \& READ, 2008). The AMF are obligatory biotrophic microorganisms, as they require association with plant roots to complete their life cycle. In this relationship, the AMF transfer water and nutrients from the soil to the plant, while the plant provides photoassimilates to the fungi (BI et al., 2005). The AMF hyphal network penetrates the roots and spreads into the soil, becoming an extension of the root system, increasing the volume and nutrient absorption efficiency of the soil (SMITH \& READ, 2008).

The AMF provide a number of benefits to surrounding plants and the environment (BERRUTI et 
al., 2015). Among the direct benefits, the best known is the largest nutrient uptake, notably phosphorus (P), due to the low mobility of this nutrient in the soil (SMITH \& READ, 2008). In addition to the higher $\mathrm{P}$ contribution, it is recognized that AMF can contribute to plant growth through other mechanisms, such as greater tolerance to water deficit (GARG \& CHANDEL, 2010), nutrient supply (SHARIF et al., 2011; HART \& FORSYTHE, 2012; DANIA et al., 2013), root protection against pathogen attack (JUNG et al., 2012), soil organic matter (SOM) accumulation through the formation and aggregation of soil (RILLING et al., 2002; RILLIG, 2004), and stimulation of the metabolic activity of other microorganisms (RILLIG \& MUMMEY, 2006).

While AMF have effects on plant growth and nutrition, physical, chemical and biological characteristics of the soil also influence the establishment of the symbiosis. Several researchers have explored the effect of different soil $\mathrm{P}$ concentrations on the potential of AMF (SMITH et al., 2011; CELY et al., 2016) and showed the existence of signaling occurring between plants and different AMF species, which vary according to soil characteristics.

Currently, more than 300 species of AMF are described (SCHÜBLER \& WALKER, 2019). Rhizophagus intraradices (NC Schenck \& GS Sm.) C. Walker and A. Schüßler (until recently classified as Glomus intraradices) is a generalist AMF species, and the list of plants that benefits by the association with $R$. intraradices includes important crops such as corn (GUO et al., 2014), soybeans (SPAGNOLETTI \& LAVADO, 2015), beans (TAJINI et al., 2012), wheat (ARDAKANI et al., 2011) and cotton (ORAK \& DEMIR, 2011).

Despite the potential of AMF for the application in agriculture, the production process bumps into its obligatory symbiotic character, which makes it difficult to produce large volumes of propagules in a short period, an essential feature to enable the application in annual crops that represent large areas of agricultural production such as maize. Traditional models of multiplication of AMF are based on the use of trap plants or plant tissue culture (VOSÁTKA et al., 2012; BERRUTI et al., 2015), but there are still few reports in the literature about an efficient production process that would be able to supply the Brazilian agricultural market with arbuscular mycorrhizal inoculants. Therefore, evaluating the agronomic efficiency of inoculants based on FMA in different edaphoclimatic conditions and management systems is important, since the chemical, physical and biological conditions of the soil influence the life cycle of AMF and the symbiotic establishment of plants of interest in agricultural production (SMITH \& READ, 2008).

The technical and scientific community and farmers have shown interest in sustainable practices. In that respect, studies to introduce, maintain, and increase AMF populations in production systems, seeking to ensure higher yields for more sustainable agricultural production are required to prove the effects of AMF inoculants.

Thus, the objective of this research was to evaluate the field agronomic efficiency of a commercial AMF-inoculant containing propagules of $R$. intraradices, in combination to different phosphate fertilization levels, in the growth and yield of corn in five different edaphoclimatic locations in Brazil.

\section{MATERIALS AND METHODS}

Experiments were carried out in the field to validate the efficiency and viability of the AMFbased inoculant, following the protocols imposed by MAPA (Ministry of Agriculture, Livestock and Supply) for product registration of plant growth promoting microorganisms, following the IN SDA 13 from 03/25/2011 (BRASIL, 2011) and IN SDA 53, from 10/24/2013 (BRASIL, 2013). Among the main requirements for the registration of microbial inoculants, there is the need to demonstrate the agronomic efficiency of the product in at least four locations of the country with distinct edaphoclimatic conditions.

Experiments were conducted in the 2016/2017 crop cycle (September 2016 to March 2017), considering the planting dates, cultivars and agricultural driving practices of each tested location. For this, five representative locations with distinct edaphoclimatic characteristics were selected (Table 1).

All fertilization procedures (based on soil analysis and expected corn yield) (SBCS, 2004), and crop treatment followed the recommendations for each location. The experiments were conducted until the plants completed the grain pre-maturation cycle. Harvest was done when corn grains were in the kernel dough to kernel dent stages (R4-R5), that is, the phase immediately before physiological maturation (MAGALHÃES \& DURÃES, 2006).

In the municipality of Xanxerê (SC), the experiment was implemented in randomized blocks, since sowing was manual. In the other locations, where sowing was mechanized, the experiments were implemented in split plots. In all cases the experiments followed a 2 × 3 factorial scheme (inoculated and noninoculated seeds in the plots), with three phosphate 
Table 1 - Information on sowing, harvesting, cultivar, soil characteristics, chemicals and agronomic practices employed in each location.

\begin{tabular}{|c|c|c|c|c|c|c|c|}
\hline \multirow[t]{2}{*}{ State/ municipality } & \multirow{2}{*}{$\begin{array}{c}\text { Sowing } \\
\text { date }(2016)\end{array}$} & \multirow{2}{*}{$\begin{array}{l}\text { Harvesting } \\
\text { date }(2017)\end{array}$} & \multirow{2}{*}{$\begin{array}{c}\text { Plant density } \\
\text { (working area) }\end{array}$} & \multirow[t]{2}{*}{ Cultivar } & \multicolumn{3}{|c|}{-------------Soil characteristics------------ } \\
\hline & & & & & $\begin{array}{c}\text { Clay } \\
\left(\mathrm{g} \mathrm{kg}^{-1}\right)\end{array}$ & $\begin{array}{c}\mathrm{P} \\
\left(\mathrm{mg} \mathrm{dm}^{-3}\right)^{\dagger *}\end{array}$ & $\begin{array}{c}\mathrm{N}^{\S}-\mathrm{P}_{2} \mathrm{O}_{5}-\mathrm{K}_{2} \mathrm{O} \\
\left(\mathrm{kg} \mathrm{ha}^{-1}\right)\end{array}$ \\
\hline $\begin{array}{l}\text { GO -Padre Bernardo } \\
\left(15^{\circ} 12^{\prime} 29.9^{\prime \prime S}\right. \\
\left.48^{\circ} 26^{\prime} 28.6^{\prime \prime} \mathrm{W}\right)\end{array}$ & Nov 23 & Mar 07 & 40 & LG 6038 & 600 & $6.71(\mathrm{M})$ & $120-80-40$ \\
\hline $\begin{array}{l}\text { MG - Ritápolis } \\
\left(20^{\circ} 59^{\prime} 39.1^{\prime \prime S}\right. \\
\left.44^{\circ} 24^{\prime} 15.4^{\prime \prime} \mathrm{W}\right)\end{array}$ & Oct 26 & Mar 09 & 62 & $\begin{array}{l}\text { DKB } 390 \\
\text { VT PRO } 3\end{array}$ & 230 & $1.10(\mathrm{VL})$ & $120-100-70$ \\
\hline $\begin{array}{l}\text { MT - Tangará da Serra } \\
\left(14^{\circ} 26^{\prime} 43.7^{\prime \prime S}\right. \\
\left.58^{\circ} 02^{\prime} 14.4^{\prime \prime} \mathrm{W}\right)\end{array}$ & Nov 07 & Feb 15 & 84 & $\begin{array}{c}\text { DKB } 390 \\
\text { VT PRO } 3\end{array}$ & 680 & $4.80(\mathrm{M})$ & $120-100-70$ \\
\hline $\begin{array}{l}\mathrm{RS} \text { - Cachoeira do Sul } \\
\left(30^{\circ} 16^{\prime} 35.7^{\prime \prime S}\right. \\
\left.52^{\circ} 53^{\prime} 07.4^{\prime \prime} \mathrm{W}\right)\end{array}$ & Sep 04 & Mar 01 & 96 & $\begin{array}{c}\text { DOW2A } \\
401\end{array}$ & 260 & $16.0(\mathrm{H})$ & $110-110-90$ \\
\hline $\begin{array}{l}\mathrm{SC}-\text { Xanxerê } \\
\left(26^{\circ} 55^{\prime} 09.2^{\prime \prime} \mathrm{S}\right. \\
\left.52^{\circ} 22^{\prime} 50.8^{\prime \prime} \mathrm{W}\right)\end{array}$ & Sep 23 & Feb 28 & 68 & $\begin{array}{c}\text { LG } 6033 \\
\text { PRO2 }\end{array}$ & 340 & $5.70(\mathrm{M})$ & $120-50-115$ \\
\hline
\end{tabular}

${ }^{\dagger} \mathrm{P}$ determined by Mehlich 1 .

${ }^{\S}$ Of the recommended, $20 \mathrm{~kg}$ were applied at sowing and the remaining broadcasted 45 days after planting.

${ }^{\#}$ Evaluations were based on the same number of plants per working area (30 plants).

${ }^{*}$ Levels of P in the soil. VL: very low; M: medium; H: high. Classes determined according to fertilizer recommendation system for each location.

fertilization treatments (no fertilization, 50\%, and $100 \%$ of the recommended P) in 6 replications.

The experimental plots (36 plots per location) were assembled with an area of $24 \mathrm{~m}^{2}(4 \mathrm{~m}$ x $6 \mathrm{~m}$ ), occupying a total area of $1,333 \mathrm{~m}^{2}$ (already considering 1 meter spacing between plots). The working area of each plot consisted of the central 10 $\mathrm{m}^{2}$ portion of each plot (6 lines spaced by $0.5 \mathrm{~m} \mathrm{x} 4$ linear meters).

The tested product, under the trade name of Rootella BR (registered under No. 22902 10000-0), is obtained through a hybrid system of fungal propagule production using trap plants (BERRUTI et al., 2015) and tissue culture (DIOP, 2003; SRINIVASAN et al., 2014; SCHUESSLER, 2015), and the production process employed in the formulation cannot be presented because it is under industrial secrecy.

The product was characterized and its purity certified. The number of propagules, the exclusive presence of propagules of $R$. intraradices and the strain ID was also determined in this study in the laboratory of microorganisms and biotechnological processes at UFSC. The identification approach considered characteristics inherent to fungal spores, such as number, thickness, coloration, and ornamentation of the layers that cover the spore (https://invam.wvu.edu/). For the inoculant quantification, the Most Probable Number (MPN) method (OBLINGER \& KOBURGER, 1975) was adopted to prove the concentration of 2,500 propagules per gram of product (Rootella BR), as indicated in the product label.

Seeds were inoculated with the initial addition of a liquid adhesive (Symbiosis Pró) and subsequent incorporation of the inoculant at the time of sowing following the adhesive manufacturer's recommendation (Líder Agronegócios). The recommended amount of inoculant tested in the study (Rootella BR) was $1 \mathrm{~kg}$ $\mathrm{ha}^{-1}$, regardless of plant stand used, which assured a concentration of $2,500,000$ propagules ha ${ }^{-1}$, a quantity confirmed by the MPN assays. The inoculant tested contains a mixed composition of spores and other fungal propagules (hyphae), and is formulated using sterile ultrafine vermiculite as inert vehicle. The non-inoculated treatment consisted of sowing the seeds using only the inert vehicle. For the inoculated treatments, seeds were homogenized with the mycorrhizal inoculant with the aid of plastic containers previously disinfected.

Crop management adopted in each location is described in table 2. For two of the evaluated states (RS and SC), seeds were treated with 
Table 2 - Edaphoclimatic characteristics and fungicides applied in each location.

\begin{tabular}{|c|c|c|c|c|c|c|}
\hline State & $\begin{array}{l}\text { Soil } \\
\text { type }\end{array}$ & $\mathrm{pH}\left(\mathrm{H}_{2} \mathrm{O}\right)$ & $\begin{array}{c}\text { Average } \\
\text { temperature }\left({ }^{\circ} \mathrm{C}\right)\end{array}$ & $\begin{array}{l}\text { Precipitation } \\
\text { (mm/year) }\end{array}$ & $\begin{array}{c}\text { Fungicides applied } \\
\text { via seed }\end{array}$ & $\begin{array}{l}\text { Fungicides applied during } \\
\text { plant growth }\end{array}$ \\
\hline GO & $\mathrm{RL}^{1}$ & 5.3 & 22.9 & 1431 & No application & No application \\
\hline MG & $\mathrm{SCL}^{2}$ & 5.3 & 19.2 & 1456 & No application & No application \\
\hline MT & $\mathrm{RYL}^{3}$ & 6.0 & 24.8 & 1830 & No application & No application \\
\hline RS & $\mathrm{RU}^{4}$ & 5.1 & 19.4 & 1692 & $\operatorname{Maxim} \mathrm{XL}^{\dagger}$ & Fox \\
\hline $\mathrm{SC}$ & $\mathrm{BL}^{5}$ & 5.4 & 16.3 & 2373 & Maxim XL & No application \\
\hline
\end{tabular}

${ }^{1}$ Red Latosol; ${ }^{2}$ Sandy Clay Loam; ${ }^{3}$ Red-yellow Latosol; ${ }^{4}$ Red Udult; ${ }^{5}$ Brown Latosol.

'Maxim XL: Fludioxonil + Metalaxyl-M.

${ }^{\star}$ Fox: Trifloxystrobin + Protioconazol.

specific fungicides before planting. In addition to seed treatment, fungicides were also used during the crop cycle in the state of RS. The choice of products was based on the fungal disease identified in each evaluated location. Weed and insect control were carried out using specific herbicides and insecticides for each situation, respectively.

In compliance with the minimum requirements established by IN SDA 13 from 03/25/2011 (BRASIL, 2011) and IN SDA 53, from 10/24/2013 (BRASIL, 2013), dry biomass of shoots, grain yield, $\mathrm{P}$ content and accumulation in the shoot biomass were evaluated. For that purpose, 30 plants were collected at the R4-R5 phenological stages from the four central lines of each plot (10 $\mathrm{m}^{2}$ working area). The biomass was dried in a forced air circulation oven at $60{ }^{\circ} \mathrm{C}$ until weight stabilization. Grain yield was determined from the grain yield of the working area of each plot, based on the yield obtained for the 30 plants evaluated per plot.

The contents and accumulation of $\mathrm{P}$ were determined from a sample composed of 10 leaves collected in different portions of plants randomly selected in the working area of each plot following the method described by TEDESCO et al. (1995). The leaf closest to the last ear was collected at the time of the appearance of female inflorescences. Two-way analysis of variance was performed and the separation of means obtained by Tukey's test at $5 \%$ probability using the software SISVAR v.5.3.

\section{RESULTS AND DISCUSSION}

In this experiment, the mycorrhizal inoculant significantly increased corn biomass in all sampled locations regardless of $\mathrm{P}$ rates applied (Table 3), confirming that proposed by CAVALCANTE et al. (2009) that corn is a species with high responsiveness to the inoculation of arbuscular mycorrhizal fungi. There was an average increase of $48 \%$ in biomass in the inoculated plants compared to the noninoculated, with an amplitude of 13 to $122 \%$. In most places, corn biomass increase in the low and medium $\mathrm{P}$ inoculated treatment-locations was equal to or higher than the non-inoculated treatment with the recommended dose of $P$.

As observed in the present study, CELEBI et al. (2010) demonstrated the positive effect of AMF for the growth of maize, with an average increase of $31 \%$ in dry biomass for the AMF-inoculated maize varieties. SHARIF et al. (2011) verified average increases of $14 \%$ in shoot biomass, while KHALIL et al. (1994) demonstrated up to $400 \%$ increases in growth for the AMF-inoculated maize varieties. These results demonstrate the effects that AMF exert on plants, such as higher absorption of $\mathrm{N}$ (up to $75 \%$ ) and $\mathrm{P}$ (up to $80 \%$ ).

There is well-documented evidence that AMF contribute to increase the availability and uptake of $\mathrm{P}, \mathrm{N}$ and micronutrients (KRISHNA \& BAGYARAJ, 1991; SMITH \& READ, 2008). The mycorrhizal symbiosis, by linking the biotic and geochemical portions of the ecosystem, can be regarded as the bridge between roots and the surrounding soil microhabitats, allowing for the partition of soil nutrients, including $\mathrm{N}$ and $\mathrm{P}$, in the ecosystems (TORO et al., 1997).

Arbuscular mycorrhizal symbiosis is a widespread phenomenon and there is evidence of direct effects of mycorrhizal fungi on inorganic $\mathrm{N}$ metabolism and on $\mathrm{N}$ acquisition and assimilation by symbiotic systems (AZCÓN et al., 1982; TOBAR 
Table 3 - Effect of mycorrhizal inoculant application and phosphate fertilization on the dry biomass of $\operatorname{corn}\left(\mathrm{Mg} \mathrm{ha}^{-1}\right)$.

\begin{tabular}{|c|c|c|c|c|c|c|c|c|c|c|}
\hline \multirow{4}{*}{$\begin{array}{l}\text { Applied } \\
\text { P (\%) }\end{array}$} & & & & & \multirow{4}{*}{\multicolumn{2}{|c|}{$\mathrm{RS}\left(\mathrm{Mg} \mathrm{ha}^{-1}\right)$}} & & & & \\
\hline & & & & & & & & & & \\
\hline & \multicolumn{2}{|c|}{ MT $\left(\mathrm{Mg} \mathrm{ha}^{-1}\right)$} & \multicolumn{2}{|c|}{$\mathrm{GO}\left(\mathrm{Mg} \mathrm{ha}^{-1}\right)$} & & & \multicolumn{2}{|c|}{$\mathrm{SC}\left(\mathrm{Mg} \mathrm{ha}^{-1}\right)$} & \multicolumn{2}{|c|}{$\operatorname{MG}\left(\mathrm{Mg} \mathrm{ha}^{-1}\right)$} \\
\hline & $\mathrm{NI}^{1}$ & $\mathrm{AMF}^{2}$ & NI & $\mathrm{AMF}$ & & & NI & $\mathrm{AMF}$ & NI & $\mathrm{AMF}$ \\
\hline 0 & $10.84 \mathrm{~b}$ & $20.07^{*} \mathrm{~b}$ & $15.65 \mathrm{~b}$ & $20.30^{*} \mathrm{~b}$ & $21.76 \mathrm{a}$ & $25.67^{*} \mathrm{a}$ & $19.40 \mathrm{a}$ & $36.20^{*} \mathrm{a}$ & $3.32 \mathrm{c}$ & $6.16^{*} \mathrm{~b}$ \\
\hline 50 & $17.72 \mathrm{a}$ & $22.32^{*} \mathrm{~b}$ & $15.76 \mathrm{~b}$ & $23.10^{*} \mathrm{ab}$ & $23.06 \mathrm{a}$ & $26.21^{*} \mathrm{a}$ & $19.89 \mathrm{a}$ & $34.67^{*} \mathrm{a}$ & $7.51 \mathrm{~b}$ & $16.69^{*} \mathrm{a}$ \\
\hline 100 & $15.24 \mathrm{a}$ & $25.51^{*} \mathrm{a}$ & $19.86 \mathrm{a}$ & $24.60^{*} \mathrm{a}$ & $22.91 \mathrm{a}$ & $27.13^{*} \mathrm{a}$ & $24.05 \mathrm{a}$ & $33.55^{*} \mathrm{a}$ & $10.78 \mathrm{a}$ & $18.45^{*} \mathrm{a}$ \\
\hline
\end{tabular}

*Significant effect of inoculation at $5 \%$ probability by $\mathrm{F}$ test. The mean values followed by the same letter within the same inoculation treatment do not differ from each other by Tukey's test at $5 \%$ probability.

${ }^{1} \mathrm{NI}$ : non-inoculated.

${ }^{2} \mathrm{AMF}$ : arbuscular mycorrhizal fungi.

et al., 1994a, 1994b; ATUL-NAYYAR et al., 2009). Mycorrhizal status may alter the number and activity of N-transforming microorganisms, since changes in the soil environment are expected to affect microbial groups present in the soil.

As for $\mathrm{N}$, there are several studies that show the importance of AMF on the availability and distribution of $\mathrm{P}$ within plants in different ecosystems (SMITH \& READ, 2008; SMITH \& SMITH, 2011; WALDER \& VAN DER HEIJDEN, 2015). These studies clearly establish that AMF mediate the phosphate uptake of plants and, in many cases, improve nutrition and productivity (BUCHER, 2007). Phosphate primarily uptake is mediated by the AMF arbuscules through the expression of host phosphate transporter genes (PUMPLIN et al., 2012), and high phosphate conditions significantly decrease the level of AMF colonization (BAYLIS, 1967; MOSSE, 1973; NAGY et al., 2009; BREUILLIN et al., 2010; BALZERGUE et al., 2011). It is even hypothesized that defense mechanisms participate in limiting AMF colonization in plants cultivated in phosphorus-sufficient conditions (LEHNERT et al., 2017). A recent study has shown that the supply of exogenous phosphate leads to a rapid $(<5 \mathrm{~h})$ suppression in arbuscule development and temporarily inhibits the growth of intraradical colonization (KOBAE et al., 2016).

The literature also showed that different results of AMF may be obtained in different management conditions. For instance, areas with high levels of soil organic matter (SOM) may benefit from AMF by altering the levels of nutrient metabolism and assimilation (AZCÓN et al., 1982; TOBAR et al., 1994a, b; ATUL-NAYYAR et al.,
2009). It is also known that other practices and variables have direct effects on the performance of AMF in agricultural systems. Among them, variations in soil type, indigenous AMF community and diversity, environmental changes, crop species and cultivars, and cultivation management (VAN GEEL, 2016; HART et al., 2017; JACOBY et al., 2017; SAWERS et al., 2017; KOBAE, 2019).

Leaf $P$ content ranged from 0.8 (Ritápolis - MG) to $2.8 \mathrm{~g} \mathrm{~kg}^{-1}$ (Cachoeira do Sul - RS) (Table 4), and positive effects of the inoculation were observed in the treatments with $0 \% \mathrm{P}$ in three locations, and with $100 \% \mathrm{P}$ in the municipality of Xanxerê (SC). The $\mathrm{P}$ content in the leaves may vary depending on factors such as light, temperature, soil texture, pest and disease attack (SMITH \& READ, 2008), not depending solely on $\mathrm{P}$ supply. Therefore, the benefits of phosphate fertilization and AMF inoculation can be better observed and discussed by aggregating factors such as increments in biomass (Table 3), accumulation of P (Table 4) and grain yield (Figure 1).

The accumulation of $P$, determined based on $\mathrm{P}$ content as a function of the biomass yield, increased with the AMF inoculation (Table 4). Except for the area of Cachoeira do Sul (RS) in the treatment with $50 \% \mathrm{P}$ (location that originally had high soil available P), the positive effect of the inoculation can be observed in all treatments, where the plants inoculated presented, on average, $80 \%$ increase of $\mathrm{P}$ accumulation in relation to the non-inoculated plants (Table 4). Increments ranged from 0 to $266 \%$ for the inoculated treatments, being considered significant increases equal to or greater than $26 \%$. 
Table 4 - Effect of mycorrhizal inoculant application and phosphate fertilization on corn leaf.

\begin{tabular}{|c|c|c|c|c|c|c|c|c|c|c|}
\hline \multirow{3}{*}{$\begin{array}{l}\text { Applied } \\
\text { P }(\%)\end{array}$} & \multicolumn{2}{|c|}{-------------MT----------- } & \multicolumn{2}{|c|}{-----------GO---------- } & \multicolumn{2}{|c|}{-------------RS---------- } & \multicolumn{2}{|c|}{-----------SC----------- } & \multicolumn{2}{|c|}{-----------MG---------- } \\
\hline & $\mathrm{NI}^{1}$ & $\mathrm{AMF}^{2}$ & NI & $\mathrm{AMF}$ & $\mathrm{NI}$ & AMF & NI & AMF & NI & AMF \\
\hline & \multicolumn{10}{|c|}{ 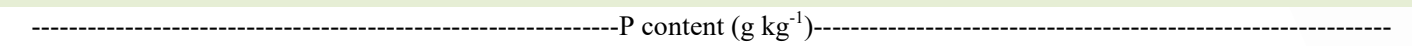 } \\
\hline 0 & $0.95 \mathrm{a}$ & $1.17 \mathrm{a}$ & $0.72 \mathrm{~b}$ & $1.67^{*} \mathrm{a}$ & $1.96 \mathrm{~b}$ & $2.72^{*} \mathrm{a}$ & $0.89 \mathrm{~b}$ & $1.65^{*} \mathrm{ab}$ & $0.75 \mathrm{a}$ & $0.92 \mathrm{a}$ \\
\hline 50 & $1.26 \mathrm{a}$ & $1.39 \mathrm{a}$ & $1.80 \mathrm{a}$ & $1.97 \mathrm{a}$ & $2.94 \mathrm{a}$ & $2.59 \mathrm{a}$ & $1.75 \mathrm{a}$ & $1.97 \mathrm{a}$ & $0.82 \mathrm{a}$ & $0.94 \mathrm{a}$ \\
\hline 100 & $1.35 \mathrm{a}$ & $1.48 \mathrm{a}$ & $1.37 \mathrm{ab}$ & $1.50 \mathrm{a}$ & $3.03 \mathrm{a}$ & $3.32 \mathrm{a}$ & $1.08 \mathrm{~b}$ & $1.43^{*} \mathrm{~b}$ & $0.79 \mathrm{a}$ & $0.70 \mathrm{a}$ \\
\hline \multirow{4}{*}{$\begin{array}{l}\text { Applied } \\
\text { P (\%) }\end{array}$} & \multicolumn{10}{|c|}{------------------------------------------------------------------------State---------------------------------------------------------------------- } \\
\hline & \multicolumn{2}{|c|}{------------MT------------ } & \multicolumn{2}{|c|}{-----------GO---------- } & \multicolumn{2}{|c|}{-----------RS-'--------- } & \multicolumn{2}{|c|}{-----------SC----------- } & \multicolumn{2}{|c|}{------------MG--------- } \\
\hline & NI & AMF & NI & AMF & NI & $\mathrm{AMF}$ & NI & AMF & NI & AMF \\
\hline & \multicolumn{10}{|c|}{ 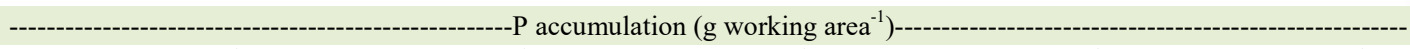 } \\
\hline 0 & $10.37 \mathrm{~b}$ & $23.45^{*} \mathrm{~b}$ & $11.25 \mathrm{~b}$ & $33.25^{*} \mathrm{a}$ & $42.71 \mathrm{~b}$ & $70.50^{*} \mathrm{ab}$ & $17.04 \mathrm{a}$ & $62.37^{*} \mathrm{a}$ & $2.42 \mathrm{~b}$ & $5.53^{*} \mathrm{~b}$ \\
\hline 50 & $22.62 \mathrm{a}$ & $31.10^{*} \mathrm{ab}$ & $28.26 \mathrm{a}$ & $45.40^{*} \mathrm{a}$ & $67.76 \mathrm{a}$ & $67.78 \mathrm{~b}$ & $34.53 \mathrm{a}$ & $68.56^{*} \mathrm{a}$ & $6.23 \mathrm{a}$ & $15.35^{*} \mathrm{ab}$ \\
\hline 100 & $19.70 \mathrm{ab}$ & $37.69^{*} \mathrm{a}$ & $26.51 \mathrm{a}$ & $36.66^{*} \mathrm{a}$ & $68.86 \mathrm{a}$ & $90.18^{*} \mathrm{a}$ & $26.19 \mathrm{a}$ & $47.59^{*} \mathrm{a}$ & $8.62 \mathrm{a}$ & $12.91^{*} \mathrm{a}$ \\
\hline
\end{tabular}

*Significant effect of inoculation at $5 \%$ probability by $\mathrm{F}$ test. The mean values followed by the same letter within the same inoculation treatment do not differ from each other by Tukey's test at $5 \%$ probability.

${ }^{1} \mathrm{NI}$ : non-inoculated.

${ }^{2}$ AMF: arbuscular mycorrhizal fungi.

Grain yield presented significant increases in all locations where there was no phosphorus application, in four locations where 50\% $\mathrm{P}$ was applied (Tangará da Serra - MT, Padre Bernardo - GO, Xanxerê - SC, e Ritápois - MG), and in three locations where $100 \%$ of the recommended $\mathrm{P}$ was applied (Tangará da Serra - MT, Padre Bernardo - GO, and Ritápois - MG.) (Figure 1). Grain yield for the inoculated over the noninoculated plants was 54\% (on average) higher, ranging from 11 to $138 \%$. In treatments where grain yield of the inoculated plants was equal to or higher than the control $(100 \% \mathrm{P}$ and not inoculated), the increases were up to $80 \%$ (Tangará da Serra-MT). Inoculated plants with $0 \% \mathrm{P}$ in the experimental area of Ritápolis (MG) did not reach the control average (100\% P and not inoculated), but presented a $90 \%$ higher grain yield when compared to the non-inoculated plants of the same dose of P. Regarding the effect of inoculation on grain yield among the different levels of available P, the largest increments were observed in the locations with the lowest $\mathrm{P}$ availability. In the municipality of Cachoeira do Sul (RS), the highest soil P available of them all, inoculation responses were less expressive, and at doses of 50 and $100 \% \mathrm{P}$, the inoculation did not provide significant increases in grain yield (Figure 1). Although, not providing significant increases in yield for the doses of 50 and $100 \% \mathrm{P}$, inoculation in the $0 \% \mathrm{P}$ in RS increased grain yield by $30 \%$, equaling the control treatment of that location (100\% P and not inoculated).
The $50 \% \quad \mathrm{P}$ inoculated treatments presented, on average, grain yields $1,490 \mathrm{~kg}$ ha- $^{-}$ ${ }^{1}$ greater than the non-inoculated $100 \% \mathrm{P}$ treatment $\left(7,100 \mathrm{~kg} \mathrm{ha}^{-1} v\right.$ s. $5,610 \mathrm{~kg} \mathrm{ha}^{-1}$, average of all locations). This represents a direct net gain of U\$ 226.48 ha $^{-1}$ (current market values). If we add to that the reduction in fertilizer application $(100 \% \mathrm{P}$ to $50 \% \mathrm{P})$, there is an additional gain of $\mathrm{U} \$ 77.10 \mathrm{ha}^{-1}$, bringing the total net gain to U\$ $303.58 \mathrm{ha}^{-1}$. In an overall estimation, the $50 \% \mathrm{P}$ inoculated treatments, presented, according to the study, an average (current market prices) of 35\% greater economic income (net gain) than the $100 \% \mathrm{P}$ non-inoculated treatments.

As seen previously in the aforementioned works, such as that of DANIA et al. (2013), inoculation with AMF promoted increases of up to $32 \%$ in corn grain yield. In the present study, the inoculant promoted even higher increments, reaching an average of $54 \%$ increment (local average, regardless of phosphate fertilization level). These results showed that the addition of the inoculant, especially in soils with low or medium available P, results in significant gains in grain yield for corn under different edaphoclimatic conditions.

\section{CONCLUSION}

The mycorrhizal inoculant Rootella BR based on $R$. intraradices increases the biomass 

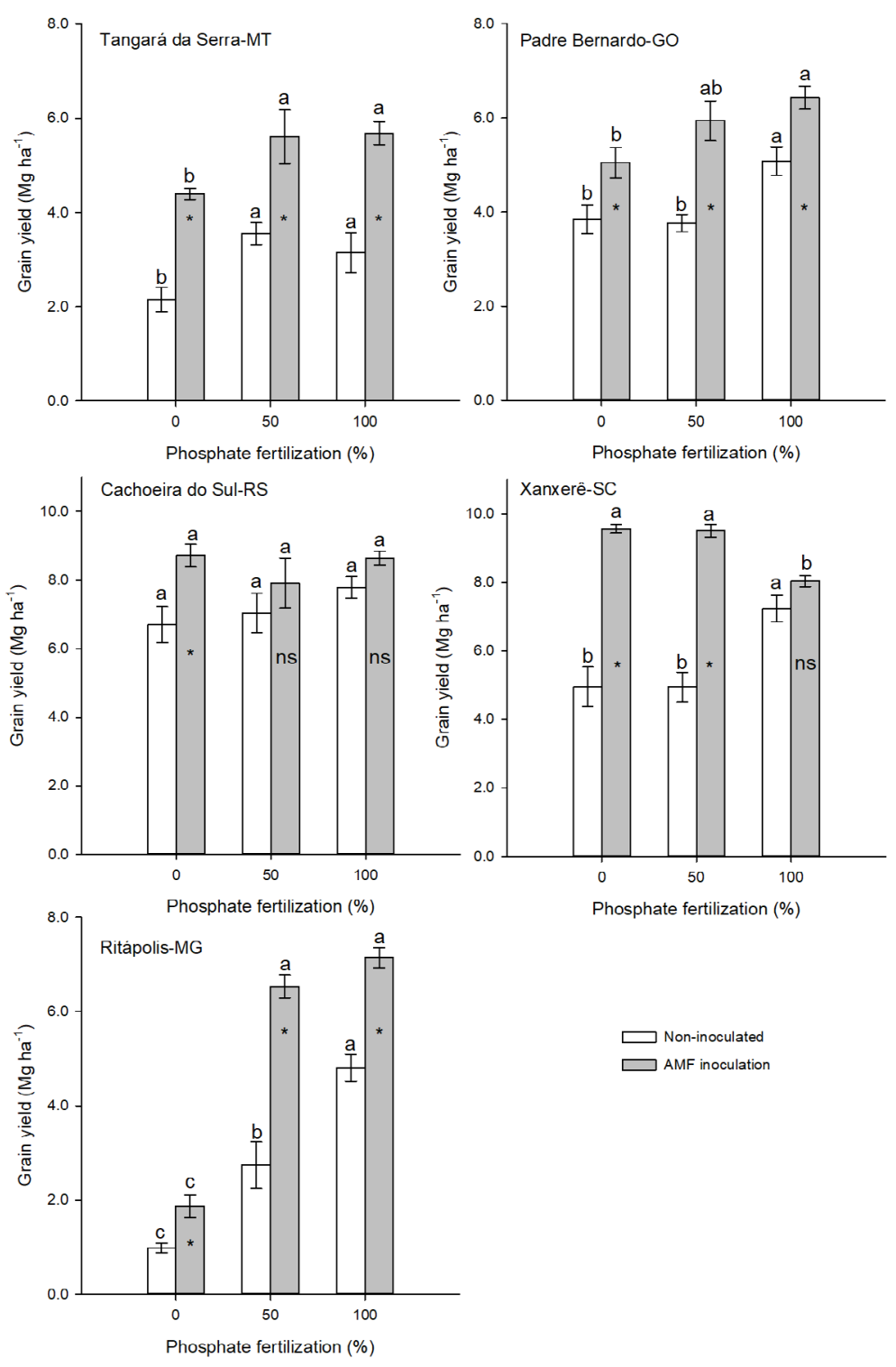

Phosphate fertilization (\%)

Figure 1 - Effect of mycorrhizal inoculant application and phosphate fertilization on grain yield of corn $\left(\mathrm{Mg} \mathrm{ha}^{-1}\right)$. ${ }^{*}$ Significant effect of inoculation at $5 \%$ probability by $\mathrm{F}$ test within $\mathrm{P}$ doses; $\mathrm{ns}=$ non-significant effect of inoculation. Vertical bars represent the standard error. Averages followed by the same letter within the same inoculation treatment do not differ by Tukey's test at $5 \%$ probability.

yield and $\mathrm{P}$ uptake by corn. Inoculation with this fungus increases the yield of corn under different edaphoclimatic conditions in Brazil, especially in soils that originally had low or medium levels of available soil $\mathrm{P}$.

\section{ACKNOWLEDGEMENTS}

This study was financed in part by the Coordenação de Aperfeiçoamento de Pessoal de Nível Superior - Brasil (CAPES) - Finance Code 001. 


\section{DECLARATION OF CONFLICT OF INTERESTS}

The authors declare no conflict of interest. The sponsors had no role in the design of the study; in the collection, analyses, or interpretation of data; in the writing of the manuscript, and in the decision to publish the results.

\section{AUTHORS' CONTRIBUTIONS}

CRFSS, PEL and AJG conceived, designed and carried out the experiments. SCGS and EM performed the laboratory analyzes. AJG supervised and coordinated the experiments. CRFSS and SCGS performed the statistical analysis of experimental data. All authors critically reviewed and approved the final version.

\section{REFERENCES}

ARDAKANI, M. R. et al., Absorption efficiency of N, P, K through triple inoculation of wheat (Triticum aestivum L.) by Azospirillum brasilense, Streptomyces sp., Glomus intraradices and manure application. Physiology and Molecular Biology of Plants, 17:181-192. 2011. Available from: <https://link. springer.com/article/10.1007\%2Fs 12298-011-0065-7>. Accessed: Nov. 1, 2018. doi: 10.1007\%2Fs12298-011-0065-7.

ATUL-NAYYAR, A.; et al. 2009. The arbuscular mycorrhizal symbiosis links $\mathbf{N}$ mineralization to plant demand. Mycorrhiza 19: 239-246. Available from: <https://link.springer. com/article/10.1007\%2Fs00572-008-0215-0>. Accessed: Nov. 3, 2019. doi: $10.1007 \% 2$ Fs00572-008-0215-0.

AZCÓN, R.; et al. Comparative effects of foliar or soil-applied nitrate on vesicular-arbuscular mycorrhizal infection in maize. New Phytologist 92: 553-559. 1982. Available from: <https:// nph.onlinelibrary.wiley.com/doi/abs/10.1111/j.1469-8137.1982. tb03414.x>. Accessed: Apr. 27, 2018. doi: 10.1111/j.14698137.1982.tb03414.x.

BALZERGUE, C.; et al. The regulation of arbuscular mycorrhizal symbiosis by phosphate in pea involves early and systemic signaling events. Journal of Experimental Botany 62: 1049-1060. 2011. Available from: <https://academic.oup.com/ jxb/article/62/3/1049/478338>. Accessed: Aug. 24, 2017. doi: $10.1093 / \mathrm{jxb} / \mathrm{erq} 335$.

BAYLIS, GTS. Experiments on the ecological significance of phycomycetous mycorrhizas. New Phytologist 66: 231-243. 1967. Available from: <https://nph.onlinelibrary. wiley.com/doi/abs/10.1111/j.1469-8137.1967.tb06001.x>. Accessed: Mar. 23, 2016. doi: 10.1111/j.1469-8137.1967. tb06001.x.

BERRUTI, A.; et al. Arbuscular Mycorrhizal Fungi as natural biofertilizers: let's benefit from past successes. Frontiers in Mycrobiology 6: 1-13. 2015. Available from: <https://www.frontiersin.org/articles/10.3389/ fmicb.2015.01559/full>. Accessed: Feb. 22, 2017. doi: 10.3389/fmicb.2015.01559.

BI, YL.; et al. Application of arbuscular mycorrhizal in ecological restoration of areas affected by coal mining in China. Acta Ecologica Sinica 25:2068-2073. 2005.
BRASIL. Ministério da agricultura, pecuária e abastecimento. Instrução normativa SDA n ${ }^{0}$ 13, de 24 de março de 2011. Altera a Instrução Normativa SARC no 05, de 6 de agosto de 2004. Diário Oficial da União: seção 1, sexta-feira, 25 de março de 2011.

BRASIL. Ministro de estado da agricultura, pecuária e abastecimento. Instrução normativa $n^{0} 53$, de 23 de outubro de 2013. Que estabelece critérios de registro e produção de inoculantes. Diário Oficial da União: seção 1, 24 de outubro de 2013.

BREUILLIN, F.; et al. Phosphate systemically inhibits development of arbuscular mycorrhiza in Petunia hybrida and represses genes involved in mycorrhizal functioning. Plant Journal 64: 1002-1017.2010. Available from: $<$ https://onlinelibrary. wiley.com/doi/abs/10.1111/j.1365-313X.2010.04385.x>. Accessed: Dec. 15, 2018. doi: 10.1111/j.1365-313X.2010.04385.x.

BUCHER, M. Functional biology of plant phosphate uptake at root and mycorrhiza interfaces. New Phytologist 173: 11-26. 2007. Available from: $<$ https://nph.onlinelibrary.wiley.com/doi/fu 11/10.1111/j.1469-8137.2006.01935.x>. Accessed: Feb. 23, 2018. doi: 10.1111/j.1469-8137.2006.01935.x.

CAVALCANTE, U. M. T.; et al. General aspects of arbuscular mycorrhizal symbiosis. Anais da Academia Pernambucana de Ciência Agronômica 5: 180-208. 2009.

CELEBI, S. Z.; et al. The effect of Arbuscular Mycorrhizal Fungi (AMF) applications on the silage maize (Zea mays L.) yield in different irrigation regimes. European Journal of Soil Biology 46: 302-305. 2010. Available from: <https://www. sciencedirect.com/science/article/abs/pii/S1164556310000531>. Accessed: Nov. 22, 2018. doi: 10.1016/j.ejsobi.2010.06.002.

CELY, M. V. T.; et al. Inoculant of Arbuscular Mycorrhizal Fungi (Rhizophagus clarus) increase yield of soybean and cotton under field conditions. Frontiers in Microbiology 7: 720. 2016. Available from: <https://www.frontiersin.org/articles/10.3389/ fmicb.2016.00720/full>. Accessed: Jul. 26, 2017. doi: 10.3389/ fmicb.2016.00720.

DANIA, S. O.; et al. Response of Maize-Pigeon Pea intercrop toArbuscular Mycorrhizal Fungi in nutrient depleted soil. Annual Review \& Research in Biology 3: 232-245. 2013. Available from: <http://www.journalarrb.com/index.php/ARRB/ article/view/24681/46150>. Accessed: Sep. 17, 2016.

DIOP, T. H. In vitro culture of arbuscular mycorrhizal fungi: advances and future prospects. African Journal of Biotechnology 2: 692-697. 2003. Available from: <https://academicjournals.org/ journal/AJB/article-abstract/9A5BBD611429>. Accessed: Feb. 26, 2016. doi: 10.5897/AJB2003.000-1128.

GARG, N.; CHANDEL, S. Arbuscular mycorrhizal networks: process and functions, a review. Agronomy for Sustainable Development 30: 581-599. 2010. Available from: <https://www. researchgate.net/publication/41697988_Arbuscular_mycorrhizal networks_Process_and_functions_A_review $>$. Accessed: Dec. 19, 2017. doi: $10.105 \overline{1}$ /agro/2009054.

GUO, W; et al. Contribution of arbuscular mycorrhizal fungi to the development of maize (Zea mays L.) grown in three types of coal mine spoils. Environ Science Pollution Research 21:3592-3603. 2014. Available from: <https:/link.springer.com/ article/10.1007\%2Fs11356-013-2360-z>. Accessed: Jan. 21, 2018. doi: $10.1007 / \mathrm{s} 11356-013-2360-\mathrm{z}$. 
HART, M. M.; FORSYTHE, J. A. Using arbuscular mycorrhizal fungi to improve the nutrient quality of crops; nutritional benefits in addition to phosphorus. Science and Horticulture148: 2012. Available from: <https://www.sciencedirect.com/science/ article/abs/pii/S0304423812004530?via\%3Dihub>. Accessed: May, 04, 2017. doi: 10.1016/j.scienta.2012.09.018.

HART, M. M.; et al. Fungal inoculants in the field: is the reward greater than the risk?. Functional Ecology 32: 126-135. 2017. Available from: <https://besjournals.onlinelibrary.wiley.com/doi/ full/10.1111/1365-2435.12976>. Accessed: Feb. 15, 2019. doi: $10.1111 / 1365-2435.12976$.

JACOBY, R.; et al. The role of soil microorganisms in plant mineral nutrition-current knowledge and future directions. Frontiers in Plant Science 8:1-19. 2017. Available from: $<$ https:// www.frontiersin.org/articles/10.3389/fpls.2017.01617/full>. Accessed: Oct. 29, 2018. doi: 10.3389/fpls.2017.01617.

JUNG, SC.; et al. Mycorrhiza-induced resistance and priming of plant defenses. Journal of Chemical Ecology 38: 651-664. 2012. Available from: <https://link.springer.com/article/10.1007 \%2Fs10886-012-0134-6>. Accessed: Jun. 14, 2017. doi: 10.1007/ s10886-012-0134-6.

KHALIL, S.; et al. Mycorrhizal dependency and nutrient uptake by improved and unimproved corn and soybean cultivars. Agronomy Journal 86: 949-958. 1994. Available from: $<$ https://acsess.onlinelibrary.wiley.com/doi/abs/10.2134/agronj1 994.00021962008600060005x>. Accessed: Nov. 12, 2018. doi: 10.2134/agronj1994.00021962008600060005x.

KOBAE, Y. Dynamic phosphate uptake in arbuscular mycorrhizal roots under field conditions. Frontiers in environmental Science 6: 1-12. 2019. Available from: $<$ https:// www.frontiersin.org/articles/10.3389/fenvs.2018.00159/full>. Accessed: Aug. 15, 2019. doi: 10.3389/fenvs.2018.00159.

KOBAE, Y.; et al. Phosphate treatment strongly inhibits new arbuscule development but not the maintenance of arbuscule in mycorrhizal rice roots. Plant Physiology 171: 566-579. 2016 Available from: <http://www.plantphysiol.org/content/171/1/566>. Accessed: Apr. 1, 2017. doi: 10.1104/pp.16.00127.

KRISHNA, K. R.; BAGYARAJ, D. J. Role of vesicular arbuscular mycorrhiza in the uptake of micronutrient by groundnut plants. Current Research 20: 173-175. 1991.

LEHNERT, H.; et al. Genetics of mycorrhizal symbiosis in winter wheat (Triticum aestivum). New Phytologist 215: 779791. 2017. Available from: <https://nph.onlinelibrary.wiley.com/ doi/full/10.1111/nph.14595>. Accessed: Jan. 2, 2017. doi: 10.1111/ nph. 14595.

MAGALHÃES, PC.; DURÃES, FOM. Fisiologia da produção de Milho. Ministério da Agricultura, Pecuária e Abastecimento (MAPA), Circular Técnica 76. 10 p. 2006.

MOSSE, B. Plant growth responses to vesicular-arbuscular mycorrhiza IV. in soil given additional phosphate. New Phytologist 72: 127-136. 1973. Available from: <www.jstor.org/ stable/2430624>. Accessed: Dec. 12, 2018.

NAGY, R.; et al. Mycorrhizal phosphate uptake pathway in tomato is phosphorus-repressible and transcriptionally regulated. New Phytologist 181: 950-959. 2009. Available from: <https://nph.onlinelibrary.wiley.com/doi/full/10.11 11/j.1469-8137.2008.02721.x>. Accessed: Oct. 27, 2017. doi: $10.1111 / \mathrm{j} .1469-8137.2008 .02721 . x$.

OBLINGER, J. L.; KOBURGER, J. A. Understanding and Teaching the Most Probable Number Technique. Journal of Milk and Food Technology 38: 540-545. 1975. Available from: $<$ https://meridian.allenpress.com/jfp/article/38/9/540/424679/ Understanding-and-Teaching-the-Most-Probable $>$. Accessed: Jun. 21, 2016. doi: 10.4315/0022-2747-38.9.540.

ORAK, A. B.; DEMIR, S. Effects of Arbuscular Mycorrhizal Fungus and Different Phosphorus Doses Against Cotton Wilt Caused by Verticillium dahliae Kleb. Plant Pathology Journal 10: 108-114. 2011. Available from: < https://scialert.net/abstract/ ?doi=ppj.2011.108.114>. Accessed: May, 23, 2018. doi: 0.3923/ ppj.2011.108.114.

PUMPLIN, N.; et al. Polar localization of a symbiosis-specific phosphate transporter is mediated by a transient reorientation of secretion. Proceedings of the National Academy of Sciences 109:665-672. 2012. Available from: <https://www.pnas.org/ content/109/11/E665>. Accessed: Aug. 22, 2017. doi: 10.1073/ pnas. 1110215109 .

RILLIG, M. C. Arbuscular mycorrhizae, glomalin, and soil aggregation. Canadian Journal of Soil Science 84: 355-363. 2004. Available from: <https:/www.nrcresearchpress.com/ doi/10.4141/S04-003\#.Xp9lochKjIU>. Accessed: Feb. 12, 2017. doi: 10.4141/S04-003.

RILLIG, M. C.; MUMMEY, D. L. Mycorrhizas and soil structure. New Phytologist 171: 41-53. 2006. Available from: <https://nph. onlinelibrary.wiley.com/doi/abs/10.1111/j.1469-8137.2006.01750.x $>$. Accessed: Feb. 4, 2018. doi: 10.1111/j.1469-8137.2006.01750.x.

RILLING, M. C.; et al. The role of arbuscular mycorrhizal fungi and glomalin in soil aggregation: comparing effects of five plant species. Plant and Soil 238: 325-333. 2002. Available from: $<$ https://link.springer.com/article/10.1023/A:1014483303813>. Accessed: Mar. 2, 2017. doi: 10.1023/A:1014483303813.

SAWERS, R. J.; et al. Phosphorus acquisition efficiency in arbuscular mycorrhizal maize is correlated with the abundance of root-external hyphae and the accumulation of transcripts encoding PHT1 phosphate transporters. New Phytologist 214: 632-643. 2017. Available from: <https://nph.onlinelibrary.wiley. com/doi/abs/10.1111/nph.14403>. Accessed: May, 23, 2019. doi: 10.1111/nph.14403.

SHARIF, M.; et al. Response of different crops to Arbuscular Mycorrhiza Fungal inoculation in phosphorus-deficient soil. Communications in Soil Science and Plant Analysis 42:22992309. 2011. Available from: $<$ https://www.tandfonline.com/doi/ab s/10.1080/00103624.2011.605488>. Accessed: Jun. 3, 2017. doi: $10.1080 / 00103624.2011 .605488$.

SCHÜBLER, A.; WALKER, C. The Glomeromycota species list. Edinburgh and Kew: The Royal Botanic Garden Kew, Botanische Staatssammlung Munich, and Oregon State University; Available from: <http://www.amf-phylogeny.com/amphylo species.html $>$. Accessed: Sep. 19, 2019.

SCHUESSLER, A. System and methods for continuous propagation and mass production of arbuscular mycorrhizal fungi in liquid culture. Patent WO 2015028601 A1. 2015. 
SMITH, S. E.; READ, D. J. Mycorrhizal Symbiosis, 3rd Edn. London: Academic. 2008.

SMITH, S. E.; SMITH, F. A. Roles of arbuscular mycorrhizas in plant nutrition and growth: new paradigms from cellular to ecosystem scales. Annual Review of Plant Biology 62: 227250. 2011. Available from: <https://www.annualreviews.org/ doi/10.1146/annurev-arplant-042110-103846>. Accessed: Feb. 27, 2018. doi: 10.1146/annurev-arplant-042110-103846.

SMITH, S. E.; et al. Roles of arbuscular mycorrhizas in plant phosphorus nutrition: interactions between pathways of phosphorus uptake. In: Arbuscular mycorrhizal roots have important implications for understanding and manipulating plant phosphorus acquisition. Plant Physiology 156: 10501057. 2011. Available from: <http://www.plantphysiol.org/ content/156/3/1050/tab-article-info $>$. Accessed: Oct. 12, 2017. doi: $10.1104 /$ pp.111.174581.

SOCIEDADE BRASILEIRA DE CIÊNCIA DO SOLO (SBCS). Comissão de Química e Fertilidade do Solo - RS/SC. Manual de adubação e de calagem para os estados do Rio Grande do Sul e de Santa Catarina. 10a. ed. Porto Alegre. 2004.

SPAGNOLETTI, F.; LAVADO, RS. The Arbuscular Mycorrhiza Rhizophagus intraradices Reduces the Negative Effects of Arsenic on Soybean Plants. Agronomy 5: 188-199. 2015. Available from: <https://www.mdpi.com/2073-4395/5/2/188>. Accessed: Apr. 10, 2018. doi: 10.3390/agronomy5020188.

SRINIVASAN, M.; et al. Establishing monoxenic culture of arbuscular mycorrhizal fungus Glomus intraradices through root organ culture. Journal of Applied and Natural Science 6: 290-293. 2014. Available from: <https://journals.ansfoundation. org/index.php/jans/article/view/417>. Accessed: Aug. 5, 2018. doi: 10.31018/jans.v6i1.417.

TAJINI, F.; et al. Combined inoculation with Glomus intraradices and Rhizobium tropici CIAT899 increases phosphorus use efficiency for symbiotic nitrogen fixation in common bean (Phaseolus vulgaris L.). Saudi Journal of Biological Sciences 19: 157-163. 2012. Available from: <https://www.sciencedirect. com/science/article/pii/S1319562X11000726?via\%3Dihub>. Accessed: Dec. 1, 2018. doi: 10.1016/j.sjbs.2011.11.003.
TEDESCO, M. J.; et al. Análise de solos, plantas e outros materiais. Boletim Técnico de Solos, 5. 2. ed. Porto Alegre: UFRGS.174 p. 1995.

TOBAR, R; et al. JM. Improved nitrogen uptakeand transport from ${ }^{15} \mathrm{~N}$-labelled nitrate by external hyphae ofarbuscular mycorrhiza under water-stressed conditions. NewPhytologist 126: 119-122. 1994a. Available from: <https://nph.onlinelibrary. wiley.com/doi/10.1111/j.1469-8137.1994.tb07536.x>. Accessed: Jan. 3, 2017. doi: 10.1111/j.1469-8137.1994.tb07536.x.

TOBAR, R; et al. The improvement of plant $\mathbf{N}$ acquisition from an ammonium-treated, drought-stressedsoil by the fungal symbiont in arbuscular mycorrhiza. Mycorrhiza 4: 105-108. 1994b. Available from: <https://link.springer.com/ article/10.1007/BF00203769>. Accessed: Apr. 21, 2018. doi: 10.1007/BF00203769.

TORO, M.; et al. Improvement of arbuscular mycorrhizal development by inoculation of soil with phosphate solubilizing rhizobacteria to improve rock phosphate bioavailability $\left({ }^{32} \mathrm{P}\right)$ and nutrient cycling. Applied Environmental Microbiology 63: 4408-4412. 1997. Available from: <https://aem.asm.org/ content/63/11/4408>. Accessed: May, 25, 2018. doi: 10.1128/ aem.63.11.4408-4412.

VAN GEEL, M.; et al. Application of slow-release phosphorus fertilizers increases arbuscular mycorrhizal fungal diversity in the roots of apple trees. Plant Soil 402: 291-301.2016. Available from: $<$ https://link.springer.com/article/10.1007\%2Fs11104-015-2777-x>. Accessed: Feb. 2, 2017. doi: 10.1007/s11104-015-2777-x.

VOSÁTKA, M.; et al. Development of arbuscular mycorrhizal biotechnology and industry: current achievements and bottlenecks. Symbiosis 58: 29-37. doi:10.1007/s13199-012-02089. 2012. Available from: $<$ https://link.springer.com/article/10.1007 \%2Fs13199-012-0208-9>. Accessed: Dec. 12, 2020. doi: 10.1007/ s13199-012-0208-9.

WALDER, F.; VAN DER HEIJDEN, M. G. Regulation of resource exchange in the arbuscular mycorrhizal symbiosis. Nature Plants1: 1-7.2015. Available from: <https://www.nature. com/articles/nplants2015159>. Accessed: Jul. 9, 2017. doi: 10.1038/nplants.2015.159. 